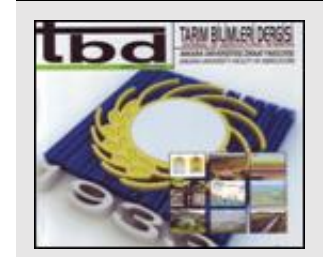

Tarım Bilimleri Dergisi Tar. Bil. Der.

Dergi web sayfası: www.agri.ankara.edu.tr/dergi
Journal of Agricultural Sciences

Journal homepage:

www.agri.ankara.edu.tr/journal

\title{
2D Analytical Model for Evaluation of the Forces in the Three-point Hitch Mechanism
}

\author{
Cerović VERA ${ }^{a}$, Milković DRAGAN ${ }^{\mathrm{a}}$, Grbović ALEKSANDAR ${ }^{\mathrm{a}}$, Petrović DRAGAN ${ }^{\mathrm{b}}$, Simonović VOJISLAV

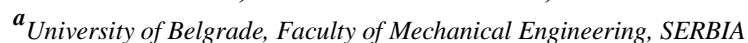

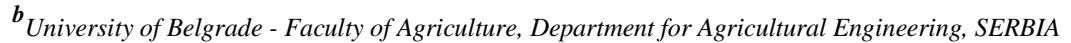

\section{ARTICLE INFO}

Research Article

Corresponding Author: Cerović VERA, E-mail: verica.cerovic@ gmail.com, Tel: +(381) 631115558

Received: 07 December 2018, Received in Revised Form: 16 March 2019, Accepted: 09 April 2019

\section{AUTHORS ORCID ID:}

(Cerović VERA: 0000-0003-2242-8895 ), (Milković DRAGAN: 0000-0002-3739-4600 ), (Grbović ALEKSANDAR: 0000-0001-9525-4270 ), (Petrović DRAGAN: 0000-0002-2442-5797 ), (Simonović VOJISLAV: 0000-0001-7698-5414 )

\begin{abstract}
Large investments, research efforts and time have been allocated till nowadays for innovation of agricultural tractors and machinery, with the primary aim to increase their productivity, reliability, durability, as well as the environmentally friendly, safe and easy usage. Following this general trend, present work is focused on theoretical analysis of the forces acting on the links of the three-point hitch mechanism. The simulation algorithm and computer code have been developed for calculation of draft forces by two methods (following ASAE D497.4 standard and Goryachkin approach), depending on the
\end{abstract}

three point linkage geometry and mouldboard technical characteristics, and calculation of forces acting on lower and upper links of three-point hitch mechanism. Calculated forces values, based on ASAE draft, exposes smaller differences compared to experimental values, while for the Goryachkin method improvement is possible by entering experimental values for soil resistance coefficient $k$ and coefficient of dynamic resistance $\varepsilon$, as we did in this study performing measurements on the aggregate comprehending tractor IMT 539 (IMT Belgrade, Serbia) and two furrow moldboard plough PTO 2.25 (OLT, Osijek, Croatia).

Keywords: Three hitch point; Tractor; Draft; Link forces

(C) Ankara Üniversitesi Ziraat Fakültesi

\section{Introduction}

Nowadays, large funds are allocated for innovation of agricultural tractors with the primary aim to increase their productivity, reliability, durability, as well as the safe and easy usage (Mileusnić et al 2010). Arizton Advistory \& Intelligence (2018) indicates that the number of low-power tractors participate a third of total sales in 2017., having the approximate growth of 5\% in some developed countries and in emerging ones in forecast period 2018-2023. Generally, about $84 \%$ of existing farms possesses less than 2 hectares, comprehending $12 \%$ of agricultural land, and even more in the less developed countries (Sarah et al 2016). Lower price, simplicity and functionality motivate owners of small farms to buy tractors with lower installed power, what was a motive to base present study on a low-power tractor.

Agricultural tractors are driving units with a wide range of possible implementations in agriculture, forestry etc. In order to provide possibility of tractors connecting with various implements applied, most of tractors are equipped with a three-point hitch mechanism (TPH). Many studies on TPH mechanisms were focused on the forces transition between tillage implements and tractors, which has the crucial influence on the operational efficiency and energy management (Dalmiş et al 2017), as we did here. 
After introducing the hydraulic system for position control, three-point linkage was improved and still remains in use in the low-power, but also in the high-power tractors. Therefore, standards recognizing four categories of these mechanisms were introduced to provide adjusting of their design to tractors having various power and traction forces.

This paper presents an analytical approach for identifying forces of three point hitch mechanism components based on the known geometry, mechanism working position, soil resistance and plough characteristics. Special computer code has been formulated, based on field measurements on the experimental parcel with known plough geometry, for assessment of forces acting on the links of the three point hitch mechanism.

During operation, the three-point linkage transfers forces acting on the implement to the tractor. Ploughing is a highly power demanding soil tillage operation (Fröba 1995), comprehending cutting and turning up and over the surface soil layer enriched with minerals and decomposed organic matter, usually in the depth range of $15 \div 30 \mathrm{~cm}$. Going deeper increases the soil resistance and consumed energy. Beside the ploughing depth, soil reactions toward plough depend on the plough design, mechanical and other soil physical parameters and the tractor speed.

\section{Material and Methods}

\subsection{The analytical model}

Forces acting on the plough can be represented with three-dimensional force vector acting on the pull center. This is not a fixed point because of the soil parameters variability, settings of the plough and connectivity with three point linkage. The lateral $R z$ force is counteracted by a landside force. The vertical force $R y$ results from the weight of the plough body, weight of the soil volume lifted by the moldboard and vertical soil force. Part of $R y$ may be also supported by gauge wheel. The longitudinal force, so-called draft resistance $R x$, is the rearward soil force component, that must be overcomed by tractor power. Dominant soil mechanical parameters influencing $R x$ are the soil deformation resistance and friction. The soil mechanical parameters changes with variations of soil texture and moisture content over depth (Haines 1925), affecting the forces acting on the links of three-point mechanism.

Variability of the soil properties imposes hard difficulties in the formulation of the general equations for the draft resistance evaluation. Draft resistance can be analytically estimated following standard ASAE (2003) Standard D497.4, 2003, and Goryachkin`s formula defined as a sum of static resistance and a dynamic resistance (Горячкин 1968)

$R_{x}=G \cdot f+k \cdot a \cdot b \cdot n+\varepsilon \cdot a \cdot b \cdot n \cdot v^{2}$

Where; $G(\mathrm{~N})$ is the plough weight; $f(-)$, represents the friction coefficient over the working element surface; $k\left(\mathrm{~N} \mathrm{~m}^{-}\right.$ ${ }^{2}$ ) is the specific soil resistance; $a(\mathrm{~m})$, designates the ploughing depth; $b(\mathrm{~m})$ is the width of ploughing tool; $n$ is the number of tools; $\varepsilon\left(\mathrm{Ns}^{2} \mathrm{~m}^{-4}\right)$, represents the coefficient of dynamic resistance, and $v\left(\mathrm{~m} \mathrm{~s}^{-1}\right)$ is tractor velocity. value.

The plough friction coefficient usually has a value $0.3 \div 0.5$ (Bernacki et al 1972), but in compact soil has a greater

The second member of equation corresponds to the energy used to cut and deform the slice of soil. Soil resistance coefficient $k$ is a function of soil type, depth, humidity, the presence of crops or residues etc. Consequently, an experimental approach was needed.

The third term corresponds to energy required for movement the slice of soil over the mouldboard and for its throwing aside. The coefficient of dynamic resistance $\varepsilon$ depends on tractor speed and shape of the mouldboard body. Its value ranges between 3000 and $10000 \mathrm{Ns}^{2} \mathrm{~m}^{-4}$ (Musil \& Červinka 2007).

In the Expression (1), influence of plough geometry on draft resistance is also given by its width $b$. For more accurate determination of plough geometry influence, an experimental approach is needed (Plouffe et al 1995).

According to ASAE Standard D497.4 draft resistance can be described by the formula

$D=F_{i} \cdot\left[A+B \cdot s+C \cdot s^{2}\right] \cdot W \cdot T$ 
Where; $F_{i}$ is parameter of soil texture ( $i=1,2,3$ for fine, medium and coarse texture respectively), $A, B, C$ are the machine parameters (for moldboard plough $\mathrm{A}=652, \mathrm{~B}=0, \mathrm{C}=5.1$ ), $W(\mathrm{~m})$ represents machine width or number of tools, $T(\mathrm{~cm})$ is the tillage depth, $s\left(\mathrm{~km} \mathrm{~h}^{-1}\right)$ designates tractor velocity. This standard provides a good estimate of average implement draft. However, changes in ground profile, soil texture and tractor ride dynamics may lead to draft amplitude of up to $\pm 50 \%$ (McLaughlin et al 2008).

The three point linkage is a 3D mechanism, consisting of the upper link, two symmetric lower links with lift rods, rockshaft arm and corresponding pins. Top and lower link set up implement into the right working position. Built in control system allows control of the implement position and/or draft force.

Fully mounted implement carries over forces to the three-hitch point. The intensity of the force depends on the position of hitching point and length of the links. Variations of the force in upper link with its length were shown by Čupera et al (2011). Tractor manufacturer usually has a test report of link length and pivot point position, measured from the rear wheel axis center. Side view of three point linkage with example of its dimensions is presented in Figure 1a. The goal of present study was to estimate forces acting on the three hitch point. Background data includes known three point linkage geometry $\left(l_{1} \div l_{6}\right)$ and position $\left(\alpha_{1} \div \alpha_{5}\right)$, estimated soil resistance $\left(R_{\mathrm{x}}, R_{\mathrm{y}}, c_{1}, c_{3}\right)$, plough weight $\left(G, c_{2}\right)$ and tractor rearwheel radius $(R)$. Position of three point linkage is determined by ploughing depth. It is not necessary to measure distance from all hitch points to the ground, but only the distance from lower link to the ground $l_{7}$, because the mast height $l_{6}$ is already known, Figure 1b. Equations $(3) \div(7)$ were developed to determine three point positions with input data presented in Figure 1a.

$$
\begin{aligned}
\alpha_{1}= & \operatorname{asin} Q_{5} \\
\alpha_{2}= & \operatorname{acos}\left[\left(l_{4}^{2}+Q_{1}+l_{2}^{2}-2 \cdot Q_{1}^{1 / 2} \cdot l_{2} \cdot \cos \left(\pi+\operatorname{atan} Q_{2}+\operatorname{asin} Q_{3}\right)-l_{3}^{2}\right) /\left(2 \cdot l _ { 4 } \left(Q_{1}+l_{2}^{2}-2 \cdot Q_{1}^{1 / 2} \cdot\right.\right.\right. \\
& \left.\left.\left.l_{2} \cdot \cos \left(\pi+\operatorname{atan} Q_{2}+\operatorname{asin} Q_{3}\right)\right)^{1 / 2}\right)\right]+\operatorname{acos}\left[\left(l_{2}-Q_{1}^{1 / 2} \cdot \cos \left(\pi+\operatorname{atan} Q_{2}+\operatorname{asin} Q_{3}\right)\right) /\left(Q_{1}+\right.\right. \\
& \left.l_{2}^{2}-2 \cdot Q_{1}^{1 / 2} \cdot l_{2} \cdot \cos \left(\pi+\operatorname{atan} Q_{2}+\operatorname{asin} Q_{3}\right)^{1 / 2}\right] \\
\alpha_{3}= & \operatorname{acos}\left[\left(l_{6}^{2}+l_{5}^{2}-Q_{4}-l_{1}^{2}+2 \cdot Q_{4}{ }^{1 / 2} \cdot l_{1} \cdot \cos \left(\operatorname{atan} Q_{5}+\operatorname{asin} Q_{3}\right) /\left(2 \cdot l_{5} \cdot l_{6}\right)\right]\right. \\
\alpha_{4}= & \operatorname{acos}\left[\left(l_{1}-Q_{4} \cdot \cos \left(\operatorname{atan} Q_{5}+\operatorname{asin} Q_{3}\right)\right) /\left(Q_{4}+l_{1}^{2}-2 \cdot Q_{4}{ }^{1 / 2} \cdot l_{1} \cdot \cos \left(\operatorname{atan} Q_{5}+\operatorname{asin} Q_{3}\right)\right)^{1 / 2}\right]+ \\
& \operatorname{acos}\left[\left(l_{6}^{2}-l_{5}^{2}+Q_{4}+l_{1}^{2}-2 \cdot Q_{4}{ }^{1 / 2} \cdot l_{1} \cdot \cos \left(\operatorname{atan} Q_{5}+\operatorname{asin} Q_{3}\right)\right) /\left(2 \cdot l _ { 6 } \cdot \left(Q_{4}+l_{1}^{2}-2 \cdot Q_{4}{ }^{1 / 2} \cdot\right.\right.\right. \\
& \left.\left.\left.l_{1} \cdot \cos \left(\operatorname{atan} Q_{5}+\operatorname{asin} Q_{3}\right)\right)^{1 / 2}\right)\right]
\end{aligned}
$$

$\alpha_{5}=\alpha_{1}+\alpha_{4}-\frac{\pi}{2}$

Where; $Q_{1}=\left(x_{2}-x_{1}\right)^{2}+\left(y_{2}-y_{1}\right)^{2} ; Q_{2}=\frac{y_{2}-y_{1}}{x_{2}-x_{1}} ; Q_{3}=\frac{R-l_{7}+y_{1}}{l_{1}} ; Q_{4}=\left(x_{3}-x_{1}\right)^{2}+\left(y_{3}-y_{1}\right)^{2} ; Q_{5}=$ $\frac{y_{3}-y_{1}}{x_{3}-x_{1}}$

Vertical component of soil force for moldboard can be related with draft force (Martinov \& Marković 2002):

$R_{y} \approx 0.14 R_{x}$

Depending on the plough design, the vertical component of soil reaction force may be supported by the gauge force, landside heel or may be completely transferred to the three point linkage. The center point of soil resistance $\mathrm{T}_{4}$ on a mouldboard plough is located halfway along the slice width and one-third of the ploughing depth by Bernacki \& Haman (1967), while Wilkinson \& Braunbeck (1977) placed center of soil resistance on one-fourth of the slice width from landside and one-fourth of the ploughing depth. 


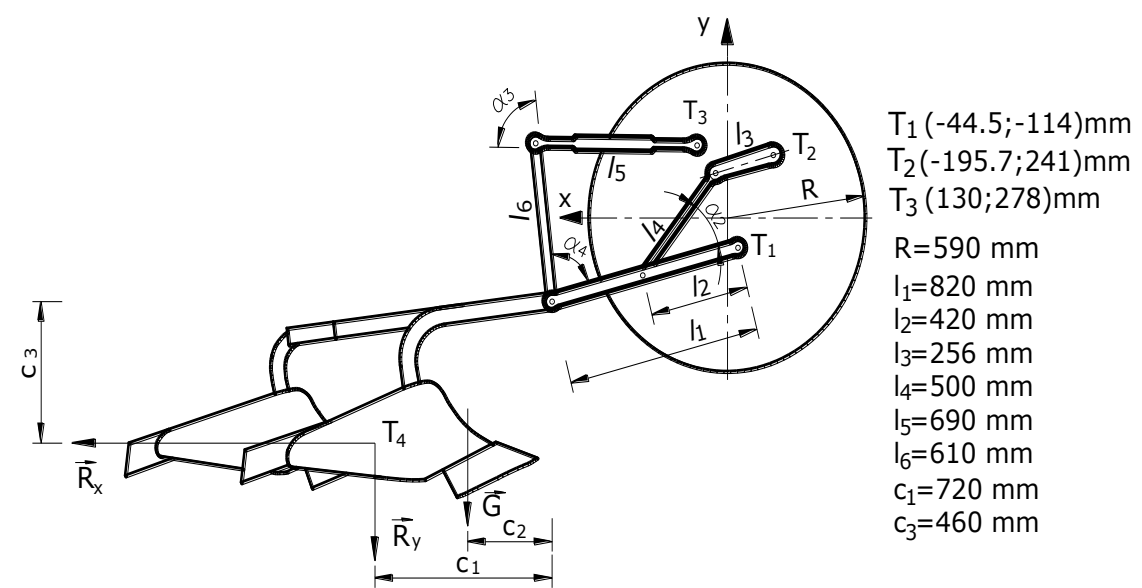

(a)

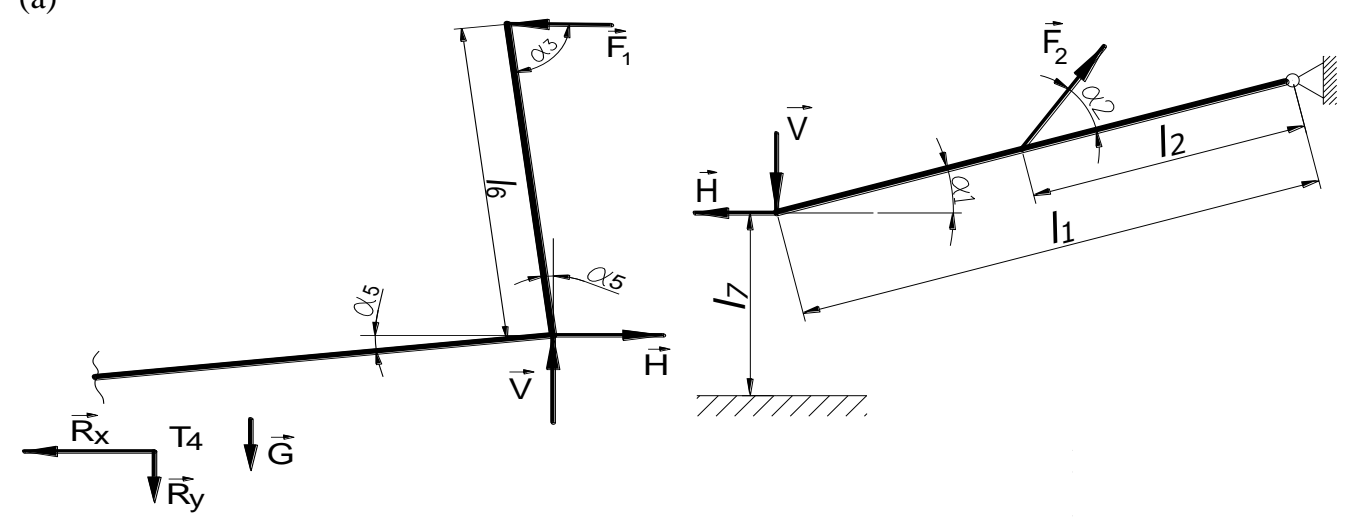

(b)

Figure 1- Three point linkage mechanism: a, three point linkage geometry; b, position of mast and lower link, and forces acting on these elements, during ploughing with forces

Implement motion is limited by three-point linkage, except it has freedom to rise up. By knowing the moving pattern (Equations (3)-(7)), it is possible to calculate forces acting on the three hitch point for each working position. The calculations only take into account the simplified 2D model of loading. Loading scenario for the mast and lower link is presented in Figure 1b. Uniform motion of tractor is assumed in this analysis, so there is no inertial force. Newton's second law gives three independent equations of equilibrium needed to determine the forces acting on the mast.

$F_{1}=\left(R_{x} \cdot c_{3}-0,1 \cdot R_{x} \cdot c_{1}-G \cdot c_{2}\right) /\left(l_{6} \cdot \sin \left(\alpha_{3}\right)\right)$

$H=\left(R_{x}+F_{1} \cdot \sin \left(\alpha_{3}+\alpha_{5}\right)\right) / 2$

$V=\left(G+0,1 \cdot R_{x}-F_{1} \cdot \cos \left(\alpha_{3}+\alpha_{5}\right)\right) / 2$

Where; $\overrightarrow{F_{1}}$ is the force acting on upper link hitch point, while $H$ and $V$ are horizontal and vertical component of force acting on both lower link hitch point.

\subsection{Experimental procedure}

Tractor IMT 539 (IMT-Belgrade, Serbia) was used in the experiment, Figure 2a. Technical characteristics of this tractor were: Diesel engine power $29.5 \mathrm{~kW}$, the mass $1789 \mathrm{~kg}$, front wheels 6.00-16', and rear wheels 11.2-28', Implement used for ploughing was two furrow semi digger moldboard plough PTO 2.25 (OLT-Osijek, Croatia), with operating width 30 $\mathrm{cm}$ per each moldboard and total mass $215 \mathrm{~kg}$, Figure $2 \mathrm{~b}$. The lower link was $820 \mathrm{~mm}$ long with eyebolts end. It was a lower link of the first (I) category. 
A field test and measuring were conducted on the flat horizontal parcel, characterized by black soil type-chernozem consisting of $35 \%$ sand, $35 \%$ silt and $30 \%$ clay, soil moisture content was $19 \%$, volume weight $1.47 \mathrm{~g} \mathrm{~cm}^{-3}$. There were remains in the ground after harvest of wheat grains.

Force was measured using custom-made force transducer based on the strain measurements using strain gauges and calibration of the developed transducer. Used strain gauges, of commercial type 3/120KY31, manufactured by Hottinger Baldwin Messtechnik, Germany, were mounted as it is explained in Cerović et al (2018), Figure 2c. Measuring resistance of these gauges are $120 \Omega \pm 1 \%$, measuring grid length $3 \mathrm{~mm}$, code number for the temperature response for ferritic steel $\alpha=10.8 \cdot 10^{-6} \mathrm{~K}^{-1}$, maximum bridge excitation voltage $8 \mathrm{~V}$, transverse sensitivity $0.1 \%$, gage factor $2.00 \pm 1 \%$. Lower link of the mechanism was equipped with strain gauges as shown in Figures 2d, 2e. Prior to measurement, calibration of the lower link was performed, (Figure 2f) and dependence between the applied force and strain measurements was estimated

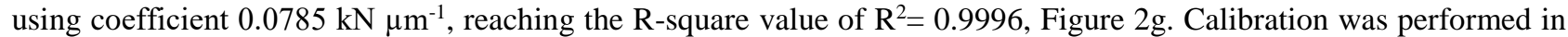
the same position as the lower link is mounted on the tractor and with a depth corresponding to middle of the range of depth selected during the experiment. Force was measured using force transducer HBM U5 $200 \mathrm{kN}$ connected with DAQ system Quantum MX840A, (Figure 2h). Strain gauges applied on the lower link were connected in to Wheatstone bridges in order to measure horizontal force and bending caused by link geometry and consequently by eccentrically acting of forces on the link joints. Power supply for DAQ system was realized using petrol generator HONDA EU10i.

After analysing the calibration data and findings of Cerović et al (2018), it was noticed that due not only the pure axial load of the lower link but also the bending moment around the vertical axis, it is better to use (mount) only longitudinal strain gauge. Due to loading direction which does not coincide ideally with the axis, transversely placed strain gauge impose an error in establishing a connection between loading and relative deformations of the strain gauge. In order to have more accurate measurements, additional sensors should be added to measure forces in all mechanism components.

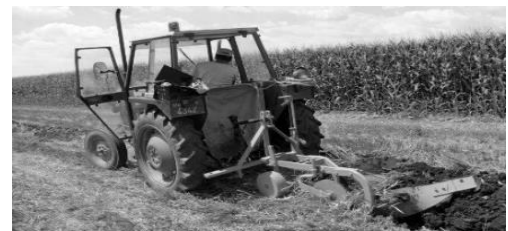

(a)

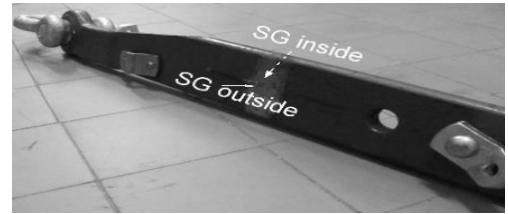

(c)

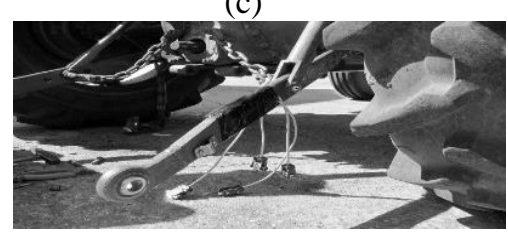

(e)

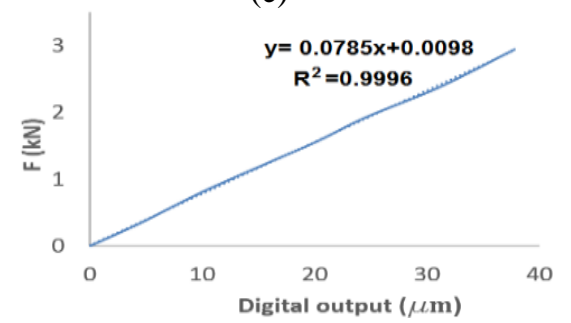

(g)

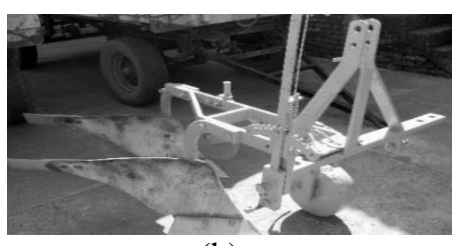

(b)

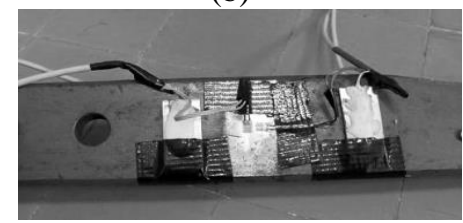

(d)

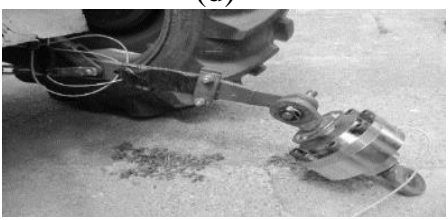

(f)

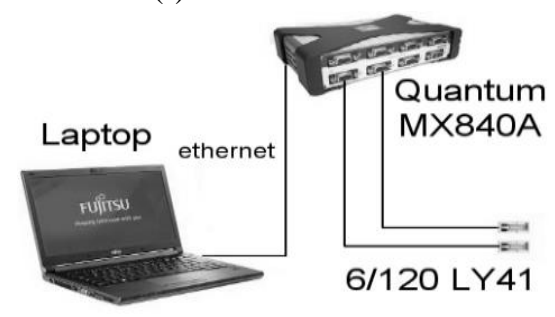

(h)

Figure 2- Experimental set-up: a, tractor in the test plot; b, two furrow moldboard plough; c, strain gauges position; d, strain gauges; e, mounting configuration directly on the lower link; f, field calibration; g, calibration line of lower link; $h$, measuring chain 
Different ploughing depths and velocities were chosen in the field experiments, according tractor power and plough specification, Table 1.

Table 1- Ploughing depth and velocity chosen for experiment

\begin{tabular}{lrrrrrrrrr}
\hline Measurement & 1 & 2 & 3 & 4 & 5 & 6 & 7 & 8 & 9 \\
\hline Depth $(\mathrm{cm})$ & 20 & 20 & 20 & 17 & 15 & 13.5 & 11 & 11 & 15 \\
Velocity $\left(\mathrm{km} \mathrm{h}^{-1}\right)$ & 2 & 4 & 6 & 2 & 2 & 2 & 2 & 6 & 6 \\
\hline
\end{tabular}

The plough was set in accordance with agro-technical requirements during all measurements. The tractor passed 50 $\mathrm{m}$ in each measurement. Measurements were repeated three times.

\section{Results and Discussion}

Measured values are shown in Figure 3. Recorded values of the measured forces showed strong fluctuations, which are mainly caused by the variations of soil resistance. Skalweit (1952) pointed out that ploughing depth tolerance should be $\pm 10 \%$ of the mean value when the ploughing depth is about $18 \div 25 \mathrm{~cm}$. Changes in ground profile and soil structure lead to variability of the measured forces. Experimentally obtained values, Figure 3, indicate a change of horizontal force in lower link with depth and velocity. Descriptive statistics of all measurements are presented in the Table 2 . Such dependence is also noticeable in both formulas for soil resistance calculation, Equation (1) and Equation (2). As the soil type affects soil resistance, it is an essential factor of equations, although the ASAE D497.4 method is somewhat simpler than the Goryachkin method. Necessary parameters of soil type and machine are given in ASAE standard. Goryachkin method is based on experimental data. Yet, some regularity was noticed for specific soil resistance coefficient $\mathrm{k}: 20 \div 40$ $\mathrm{kN} \mathrm{m}^{-2}$ for light soils (sandy, silt); $40 \div 60 \mathrm{kN} \mathrm{m}^{-2}$ for medium soils (sandy clay); $60 \div 80 \mathrm{kN} \mathrm{m}^{-2}$ for heavy soils (clay) and $80 \div 100 \mathrm{kN} \mathrm{m}^{-2}$ for very heavy soils (Martinov \& Marković 2002).

Test field chernozem is medium soil type. The third member of the equation (1) does not exceed $5 \%$ of total draft force (Borissov 2007) and therefore can be neglected. For the test, chosen value for coefficient of dynamic resistance $\varepsilon$ was $3 \mathrm{kNs}^{2} \mathrm{~m}^{-4}$. Next assumption for Goryachkin method was the value of 0.3 for the friction coefficient. After entering all data in Goryachkin Equation (1), it became obvious that the second term of the formula is dominant for small working velocity.

Based on Eqs. (1) $\div(11)$ and presented data, the computer algorithm was developed for approximate calculation of average longitudinal and vertical forces in the lower link and force in the upper link, Figure 4. An important role in the transfer of forces acting on a plough onto the links has the links geometry and position. Lengths of all links and pivot point position (sketched in the Figure 1a) were entered into the Fortran program (Adams et al 1997). After the position of links were calculated according to Eqs. $(3) \div(7)$, the program prompts how to calculate the draft: only by Equation (2) or by both Equations (1) and (2). Applied Eqs. (8) $\div(11)$ gave a simplified solution for forces.

The program has a loop for estimation of average horizontal and vertical forces acting on the lower link and force acting on the top link for different soil depths and tractor velocities. Horizontal and vertical force dependence on the tillage depth and working velocity is presented graphically in Figure 5, while Figure 6 displayed top link force change with soil depths and tractor velocities. In the Table 2 is presented the difference between measured and the calculated values for the $H$ horizontal component of force acting on the lower link hitch point. As mentioned, the ASAE standard indicates that difference up to $50 \%$ is possible between measured and calculated values for draft, and therefore for $H$ as its major part.

Calculation based on ASAE method for draft determination is easier to apply because of small number of input data. Goryachkin method can also be used for approximate calculation, but for more precise value of soil resistance the experimental values of input data are needed. Developed computer program gives approximate values for observed forces, which in real condition change on the same field because of soil texture, compaction, moisture, etc. Draft can vary from 30 to $200 \%$ (Morling R W 1979). Forces in the lower left and right link are different as well. Thus, the written program can be used to estimate the average values in links of three point hitch mechanism. 
(a)
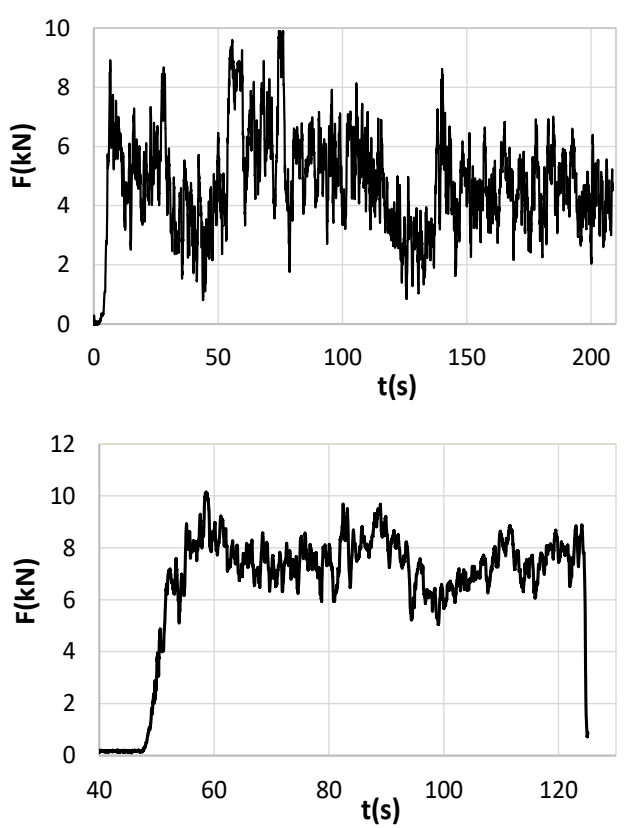

(c)

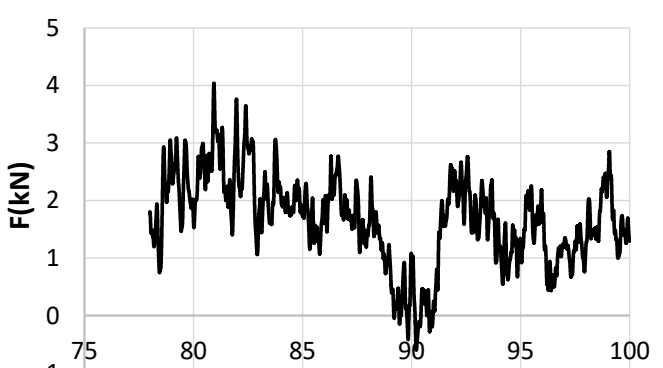

(e)
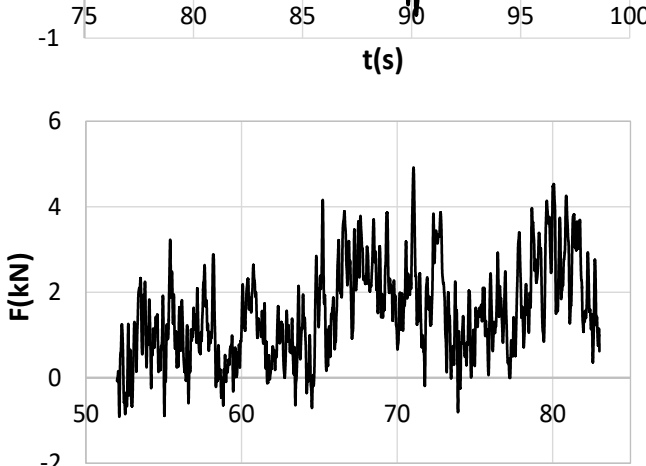

(g)

$t(s)$

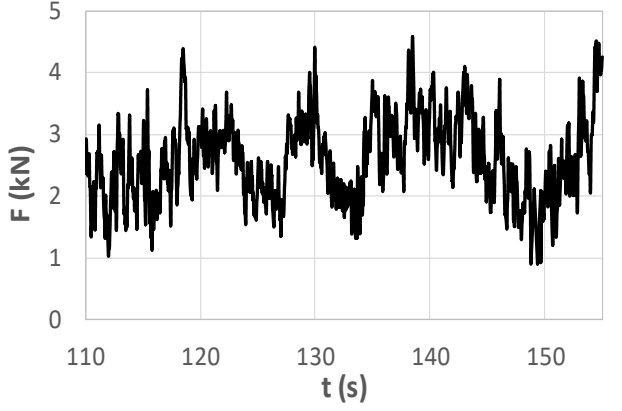

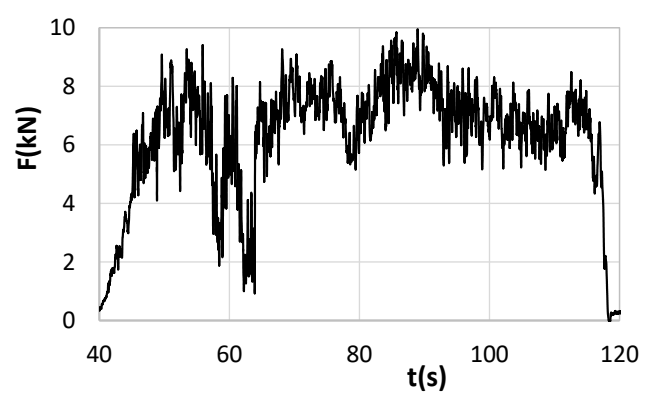

(b)

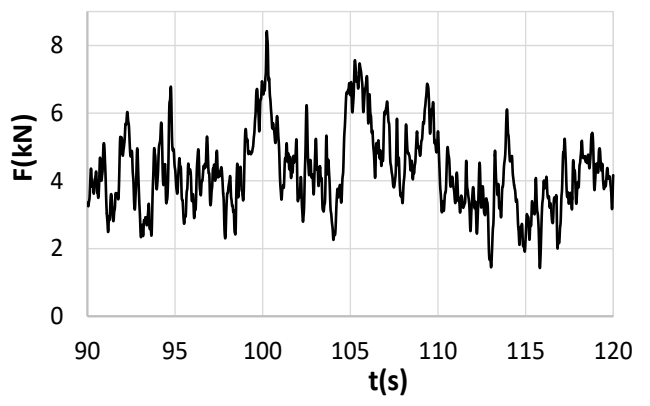

(d)

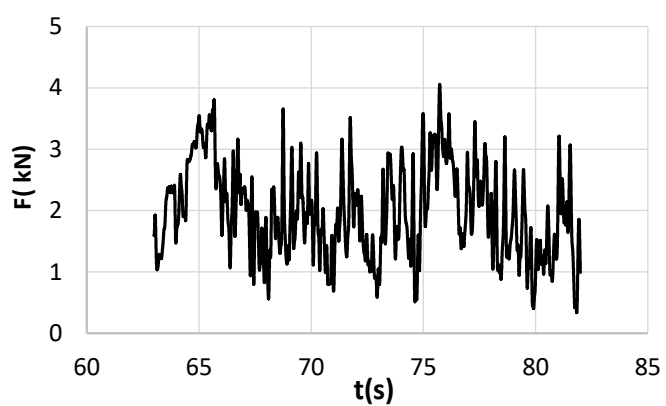

(f)

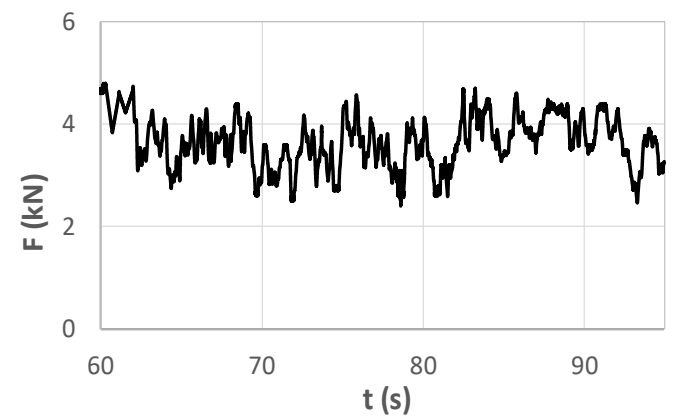

(h)

(i)

Figure 3- Sample of acquisition system data recorded for different depths and velocities. Sample measurement No.: (a) 1; (b) 2; (c) 3; (d) 4; (e) 5; (f) 6; (g) 7; (h) 8 and (i) 9, according to experimental plan listed in Table 1 
2D Analytical Model for Evaluation of the Forces in the Three-point Hitch Mechanism, Cerović et al.

Table 2- Statistical description of measurement in Table 1

\begin{tabular}{lccccccccc}
\hline Measurement & 1 & 2 & 3 & 4 & 5 & 6 & 7 & 8 & 9 \\
\hline Mean & 4.8214 & 6.8400 & 7.5448 & 3.7706 & 2.5817 & 2.1914 & 1.7851 & 2.7027 & 3.6484 \\
Standard error & 0.0045 & 0.0068 & 0.0042 & 0.0063 & 0.0052 & 0.0044 & 0.0042 & 0.0048 & 0.0037 \\
Median & 4.6847 & 7.0145 & 7.5664 & 3.7729 & 2.3598 & 2.0921 & 1.6675 & 2.6573 & 3.6712 \\
Mode & 5.0570 & 6.4582 & 6.5603 & 4.2563 & 2.1485 & 1.7798 & 1.3039 & 1.1135 & 4.3490 \\
Standard deviation & 1.5632 & 1.4132 & 0.8679 & 1.9661 & 1.3629 & 1.2014 & 1.1045 & 0.9894 & 0.76806 \\
Sample variance & 2.4436 & 1.9973 & 0.7533 & 3.8659 & 1.8576 & 1.4434 & 1.2199 & 0.9789 & 0.58991 \\
Kurtosis & 0.3803 & 2.6026 & 0.0281 & -0.723 & 0.6122 & 1.7088 & -0.2205 & -0.1901 & -0.1686 \\
Skewness & 0.5081 & -1.273 & -0.025 & 0.1485 & 0.8008 & 0.6429 & 0.353 & 0.1411 & -0.1615 \\
Range & 9.0881 & 9.0205 & 5.1049 & 10.378 & 9.7101 & 9.4947 & 6.737 & 5.2350 & 3.33323 \\
Minimum & 0.8081 & 0.9292 & 5.0466 & -1.098 & -0.948 & -1.228 & -1.5002 & 0.2399 & 1.86605 \\
Maximum & 9.8962 & 9.9498 & 10.151 & 8.8800 & 8.7619 & 8.2658 & 5.2369 & 5.4749 & 5.19929 \\
\hline
\end{tabular}

\section{Start}

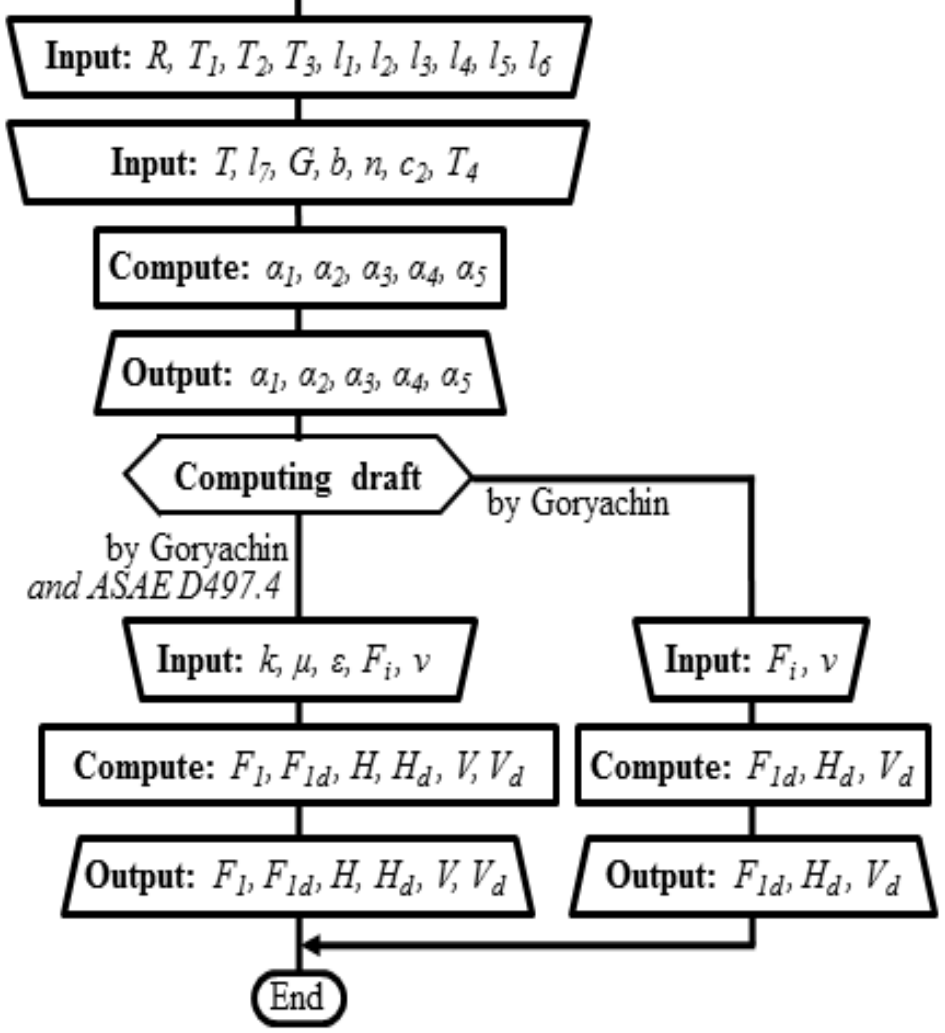

Figure 4- Block diagram representing the algorithm of the computer program 

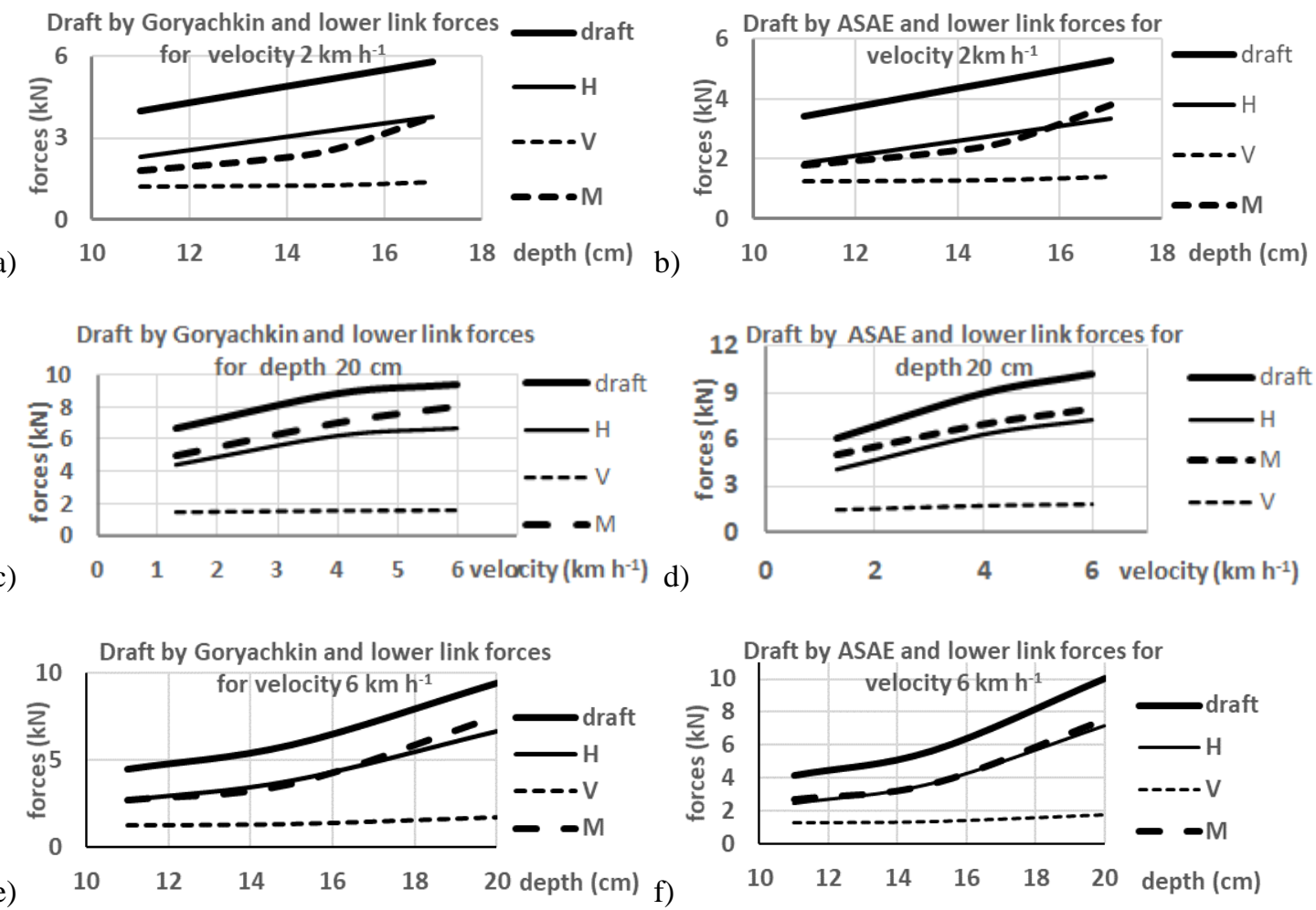

Figure 5- Graphical presentation of average values of calculated forces as dependent on the tillage depth and the tractor speed; a, change of Goryachkin draft, horizontal and vertical forces in lower link and measured forces with depth for tractor velocity $2 \mathrm{~km} \mathrm{~h}^{-1}$; b, change of ASAE draft, horizontal and vertical forces in lower link and measured forces with depth for tractor velocity $2 \mathrm{~km} \mathrm{~h}^{-1}$; c, change of Goryachkin draft, horizontal and vertical forces in lower link and measured forces with velocity for depth $20 \mathrm{~cm}$; d, change of ASAE draft, horizontal and vertical forces in lower link and measured forces with velocity for depth $20 \mathrm{~cm}$; e, change of Goryachkin draft, horizontal and vertical forces in lower link and measured forces with depth for tractor velocity $6 \mathrm{~km} \mathrm{~h}^{-1}$; f, change of ASAE draft, horizontal and vertical forces in lower link and measured forces with depth for tractor velocity $6 \mathrm{~km} \mathrm{~h}^{-1}$
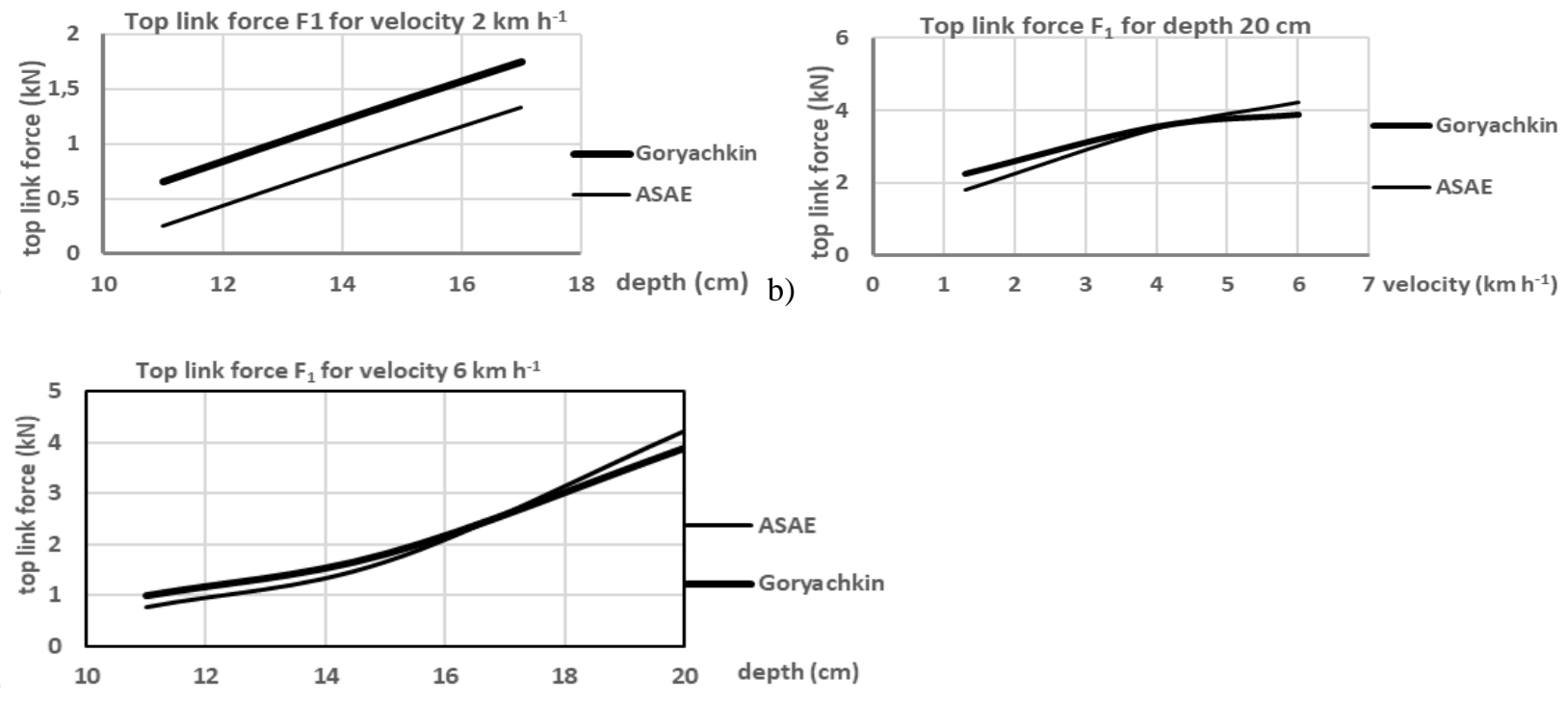

Figure 6- Graphical presentation of average values of calculated forces as dependent on the tillage depth and the tractor speed ; (a), change of top link force with depth for tractor velocity $2 \mathrm{~km} \mathrm{~h}^{-1}$; (b), change of top link force with velocity for depth $20 \mathrm{~cm}$; (c), change of top link force with depth for tractor velocity $6 \mathrm{~km} \mathrm{~h}^{-1}$ 


\section{Conclusions}

The presented work discusses the theoretical results of analysis of the forces acting on the links of the three point hitch mechanism. Computer algorithm has been developed for the simulation of these forces. Formulated model comprehends calculation of draft force by two methods (ASAE D497.4 method and Goryachkin method) and, depending on the three point linkage geometry and mouldboard technical characteristics, calculation of forces acting on lower and upper links.

The formulated mechanical model of the THP forces, expressed by equations (3-7) and (9-11) was experimentally verified. The values of the horizontal forces in the lower link obtained by two analytical methods were compared with appropriate experimental values. The application of aproximate analytical method of ASAE D497.4 for determination of the draft force resulted in mean signed difference of $0.354 \mathrm{kN}$ as it is presented in Table 3. The Goryachkin's approach of draft force evaluation generated mean signed difference of $0.449 \mathrm{kN}$. These difference can be reduced by introducing additional experimental data related to the soil properties and the mouldboard geometry in the Goryachkin's algorithm, or to apply some other more advanced method for determination of draft forces. Hence, this paper verifies the applicabillity of the analytical methods for crude estimation of the forces at the lower and upper links.

Table 3- Difference between measured and the calculated values for the $\boldsymbol{H}$ horizontal component of force acting on lower link hitch point

\begin{tabular}{lcccccccccc}
\hline Measurement & 1 & 2 & 3 & 4 & 5 & 6 & 7 & 8 & 9 & $\begin{array}{c}M_{S D^{*}} \\
(\mathrm{kN})\end{array}$ \\
\hline $\begin{array}{l}\text { ASAE } \\
\text { AD }(\mathrm{kN})\end{array}$ & 0.84 & 0.25 & 0.37 & 0.56 & 0.16 & 0.19 & 0.01 & 0.27 & 0.04 & 0.3544 \\
$\begin{array}{l}\text { Goryachkin } \\
\text { AD }^{*}(\mathrm{kN})\end{array}$ & 0.29 & 0.69 & 0.85 & 0.02 & 0.7 & 0.73 & 0.52 & 0.01 & 0.23 & 0.4489 \\
\hline
\end{tabular}

${ }^{*} \mathrm{AD}$, absolute difference; ${ }^{*} \mathrm{MSD}$, mean signed difference

Resultes presented in this paper (Figures 5-6) also indicate a general trend of increasing the horizontal forces $H$ and draft forces with plowing depth and tractor velocity. The analogue effects were evidenced with respect to the changes of top link forces $F_{1}$, with plowing depth and tractor velocity, Figure 6. Variations of the vertical lower link forces $V$ were weak.

\begin{tabular}{|ll|}
\hline Abbreviations and Symbols \\
\hline$\alpha_{1}, \alpha_{2}, \alpha_{3}, \alpha_{4}, \alpha_{5}$ & Link angles \\
$a, T$ & Ploughing depth, $\mathrm{m}$ \\
$A, B, C$ & Machine parameters \\
$b, W$ & Width of ploughing tool, $\mathrm{m}$ \\
$c_{1}, c_{3}$ & Coordinates of draft application, $\mathrm{m}$ \\
$c_{2}$ & Coordinate of plough gravity center, $\mathrm{m}$ \\
$\varepsilon$ & Coefficient of dynamic resistance, $\mathrm{Ns}^{2} \mathrm{~m}^{-4}$ \\
$f$ & Friction coefficient \\
$F_{i}$ & Parameter of soil texture \\
$F_{l}, F_{2}$ & Top link force and lift link force, $\mathrm{N}$ \\
$G$ & Plough weight, $\mathrm{N}$ \\
$H, V$ & Horizontal and vertical lower link force component, $\mathrm{N}$ \\
$k$ & Specific soil resistance, $\mathrm{N} \mathrm{m}^{-2}$ \\
$l_{l}, l_{2}, l_{3}, l_{4}, l_{5}, l_{6}$ & Three point linkage geometry, $\mathrm{m}$ \\
$l_{7}$ & Lower link hitch point distance from the ground, $\mathrm{m}$ \\
$n$ & Number of tools \\
$R$ & Tractor rear-wheel radius \\
$s, v$ & Tractor velocity, $\mathrm{m} \mathrm{s}^{-1}$ \\
\hline
\end{tabular}

\section{References}

Adams J C, Brainerd W S, Martin J T, Smith B T and Wagener J L (1997). Fortran 95 Handbook. MIT Press, USA, pp. 726 
Arizton Advistory \& Intelligence (2018). Tractor Market - Global Outlook and Forecast 2018-2023, Retrieved in October, 16, 2018 from https://www.arizton.com/market-reports/global-tractor-market-analysis

ASAE (2003). Standard D497.4, 2003, Agricultural Machinery Management Data, ASAE, St. Joseph, Michigen, USA

Bernacki H \& Haman J (1967). Grundlagen der Bodenbearbeitung und Pflugbau, Berlin VEB Verlang Technik, Berlin

Bernacki H, Haman J \& Kanafojski Cz (1972). Agricultural machines: theory and construction. Scientific Publications Foreign Cooperation Center of the Central Institute for Scientific, Technical and Economic Information, Warsaw Poland, pp. 883

Borissov B (2007). Resistance of operating equipment and agricultural machinery during progressive and rotary motion. Bulgarian Journal of Agricultural Science 13: 141-149

Cerović V, Milković D, Grbović A, Radulović S \& Tanasković J (2018). Measurement of the stress state in the lower lınk of the threepoint hitch mechanısm. In: Proceedings of International Conference of Experimental and Numerical Investigations and New Technologies, 04-06 July, Zlatibor, Serbia

Čupera J, Bauer F, Severa L \& Tatíček M (2011). Analysis of force effects measured in the tractor three-point linkage. Research Agricultural Engineering 57(3): 79-87

Dalmiş S İ, Tezcan O \& Eruslu Ö S (2017). Fatigue life enhancement of three point hitch system Brackets in the Garden series tractors. Journal of Agricultural Sciences 23(2): 185-194

Fröba N (1995). Benötigte Traktor Motorleistung bei landwirtschaftlichen Arbeiten. KTBL Arbeitsblatt Nr. 0255 in Landtechnik 50(5): $277-282$

Горячкин В П (1968). Сабрание сочинений, 2-е изд. Москва, Колос, т.2.-456 с

Haines B W (1925). Studies in the physical properties of soils: I. Mechanical properties concerned in cultivation. The Journal of Agricultural Science 15(2): 178-200

Martinov M \& Marković D (2002). Mašine i oruđa za obradu zemljišta. Fakultet tehničkih nauka u Novom Sadu, Novi Sad

McLaughlin N B, Drury C F, Reynolds W D, Yang X M, Li Y X, Welacky T W \& Stewart G (2008). Energy inputs for conservation and conventional primary tillage implements in a clay loam soil. Transaction of the ASABE 51(4): 1153-1163

Mileusnić Z, Petrović D, Miodragović R \& Dimitrijević A (2010). The influence of exploitation conditions on the tractor reliability and lifetime. Agricultural Engineering 1: 59-67

Morling R W (1979). Agricultural Tractor Hitches-Analysis of Design Requirements. American Society of Agricultural Engineers

Musil Jan \& Červinka J (2007). Measuring of pulling resistance in machinery with passive working organs. Research Argicultural Engineering 53(2): 47-53

Plouffe C, McLaughlin N B, Tessier S \& Laguë C (1995). Energy requirements and depth stability of two different moldboard plow bottoms in a heavy clay soil. Canadian Agricultural Engineering 37(4): 279-285

Sarah K L, Jakob S \& Terri R (2016). The number, size, and distribution of farms, smallholder farms, and family farms Worldwide. World Development 87: 16-29

Skalweit H (1952). Ǔber die bei der Tierhaltung von Schlepperanbaugeräten auftretenden Kräfte. Grundlagen der Landtechnik 3: 109118

Wilkinson R H \& Braunbeck O A (1977). Elements of Agricultural Machinery. Vol. 1, FAO Agricultural Services Bulletin, Rome, Italy, pp. 251 